\title{
Diagnostic Value of Platelet/Lymphocyte Ratio in the Diagnosis of Acute Appendicitis and its Relationship with Age
}

\section{Akut Appendisit Tanısında Platelet/Lenfosit Oranının Tanısal Değeri ve Yaş ile İlişkisi}

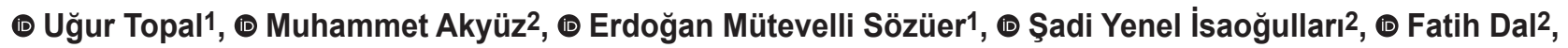 \\ (1) Tutkun Talih2
}

${ }^{1}$ Erciyes University Faculty of Medicine, Department of Surgical Oncology, Kayseri, Turkey

2Erciyes University Faculty of Medicine, Department of General Surgery, Kayseri, Turkey

\section{HIIIIII ABSTRACT}

\begin{abstract}
Aim: Acute appendicitis (AA) is one of the most common emergency surgical pathologies. The tests used in the differential diagnosis of these patients need to be quick, easy to access and cheap. Discussions continue about the value of laboratory tests in the diagnosis of AA. In this study, we aimed to determine the diagnostic value of platelet/lymphocyte ratio (PLR) in the diagnosis of AA and to determine its diagnostic value in different age groups. Method: Patients who underwent appendectomy after a preliminary diagnosis of AA between January 2015 and January 2020 were enrolled. Patients were divided into two groups, according to the postoperative pathology finding: group 1 (negative appendectomy) and group 2 (AA). In addition, groups were divided into subgroups based on age: 18-39 years, 40-59 years and 60 years and older. Platelet and lymphocyte counts and PLR were compared between groups and subgroups. In diagnostic accuracy evaluation ROC curve analysis was used; $\mathrm{p}<0.05$ value was considered statistically significant.

Results: A total of 875 patients were included in the study. There were 152 patients in group 1 (negative appendectomy) and 723 patients in group 2 (AA). Mean age was similar between the groups (33.43 vs 35.33, $\mathrm{p}=0.152$ ). In univariate analysis, lymphocyte count ( $\mathrm{p}=0.033$ ) and platelet count ( $\mathrm{p}=0.002$ ) were found to be significant. In multivariate analysis, lymphocyte count ( $\mathrm{p}=0.000$ ), platelet count ( $\mathrm{p}=0.012$ ) and PLR (odds ratio: 0.632 ; $95 \%$ confidence interval (minimum-maximum) 0.440-0.908; $\mathrm{p}=0.013$ ) were found to be significant. When the ROC curve analysis was performed, the sensitivity of PLR regardless of age was $70.82 \%$ and the specificity was $40.13 \%(\mathrm{p}=0.093)$. The highest specificity was in the $40-59$ years age group (85.71\%), the highest sensitivity was in the age group 60 and older $(78.79 \%)(\mathrm{p}=0.002)$.

Conclusion: PLR cannot be used alone in the diagnosis of AA. Normal PLR values cannot exclude AA alone. In addition, the PLR diagnostic value varies according to age groups. The surgeon's clinical evaluation should continue to be a priority in the diagnosis of AA.
\end{abstract}

Keywords: Platelet/lymphocyte ratio, acute appendicitis, age, sensitivity, specificity

\section{|IIIIIII| ÖZ}

Amaç: Akut appendisit (AA) en sık karşılaşılan acil cerrahi patolojilerden biridir. Bu hastaların ayırıcı tanısında kullanılan testlerin hızlı, kolay ulaşılabilir ve ucuz olması gerekmektedir. AA tanısının konmasında laboratuvar testlerinin değeri etrafında tartışmalar devam etmektedir. Bu çalışmada AA tanısında platelet/lenfosit oranının (PLO) tanısal değerini saptamayı ve yaş gruplarında tanısal değerinin nasıl değiştiğini saptamayı amaçladık.

Yöntem: Ocak 2015 ile Ocak 2020 tarihleri arasında AA ön tanısı ile opere edilen hastalar çalışmaya dahil edildi. Postoperatif patoloji bulgusuna göre hastalar grup 1 negatif appendektomi; grup 2 akut apandisit olmak üzere iki gruba ayrıldı. Ayrıca 18-39,40-59,60 yaş ve üstü olmak üzere subgruplara ayrıldı. Platelet, lenfosit sayısı ve PLO gruplarda ve subgruplarda karşılaştırıldı. Tanısal doğruluk değerlendirmede (ROC) eğrisi analizi kullanıldı; p<0,05 değeri istatistiksel olarak anlamlı kabul edildi.

Address for Correspondence/Yazışma Adresi: Uğur Topal MD,

Erciyes University Faculty of Medicine, Department of Surgical Oncology, Kayseri, Turkey

Phone: +90 5301139112 E-mail: sutopal2005@hotmail.com ORCID ID: orcid.org/0000-0003-1305-2056

Received/Geliş Tarihi: 01.03.2020 Accepted/Kabul Tarihi: 02.04.2020

${ }^{\oplus}$ Copyright 2020 by Turkish Society of Colon and Rectal Surgery

Turkish Journal of Colorectal Disease published by Galenos Publishing House. 
Bulgular: Toplam 875 hasta çalışmaya katıldı grup 1: 152, grup 2: 723 hastadan oluşuyordu (yaş 33,43 vs 35,33 p=0,152). Univaryant analizde lenfosit sayısı $(\mathrm{p}=0,033)$ ve trombosit sayısı $(\mathrm{p}=0,002)$ istatistiksel olarak anlamlı bulundu. Multivaryant analizde AA tanısında PLO bağımsız risk faktörüydü [olasılık oranı 0,632 \%95 güven aralığı (minimum-maksimum) 0,440 -0,908 p=0,013]. ROC eğrisi analizi yapıldığında yaştan bağımsız sensivitesi $\% 70,82$, spesivitesi \%40,13 p=0,093 idi. Yaş gruplarında en yüksek spesivite 40-59 yaş arasında \%85,71, en yüksek sensivite 60 yaş ve üstü grupta $\% 78,79 \mathrm{p}=0,002$ bulundu.

Sonuç: PLO AA tanısında tek başına kullanılamaz. Normal PLO değerleri akut apandisiti tek başına dışlayamaz. Ayrıca PLR tanısal değeri yaş gruplarına göre değişmektedir. Cerrahın klinik değerlendirmesi akut apandisit tanısında öncelikli olmaya devam etmelidir.

Anahtar Kelimeler: Platelet/lenfosit oranı, akut appendisit, yaş, sensivite, spesivite

\section{Introduction}

Acute appendicitis (AA) is the most common cause of acute abdomen presentation and appendectomy is the most common emergency surgery performed. It has been reported in the literature that the lifetime prevalence of this disease is approximately $7 \%$ and the perforation development rate in AA is $17-20 \%{ }^{1,2}$

Although the diagnosis of AA is based on clinical and laboratory data, it is still a difficult diagnosis. In adult patients, pathologies of gastrointestinal, urological or gynaecological origin can mimic AA, making the diagnosis even more difficult. There is no single laboratory marker with a diagnostic value of $100 \%$ to distinguish AA from other causes of abdominal pain. ${ }^{3}$

Optimal treatment in AA depends on early diagnosis and subsequent rapid intervention, but the decision to perform rapid appendectomy to avoid complications increases negative appendectomy rates. Traditionally, negative appendectomy has been considered acceptable to overcome morbidity and mortality. However, surgical stress is associated with postoperative morbidity and mortality, especially in advanced age groups. For this reason, caution should be exercised in appendectomy decision in older patients. ${ }^{4,5}$

The use of a number of inflammatory markers has been proposed to support clinical data in the decision-making process to ensure early diagnosis of AA and to reduce rates of misdiagnosis. Some of these are white blood cell count, erythrocyte sedimentation rate, C-reactive protein and bilirubin levels, immature granulocyte ratio, neutrophil/ lymphocyte ratio and platelet/lymphocyte ratio (PLR). ${ }^{6,7,8,9}$ While the diagnostic value of the PLR has been proven in many studies, it is still unclear how this diagnostic value is affected by age.

In this study, we aimed to determine the diagnostic value of PLR in the diagnosis of AA and to determine its diagnostic value in different age groups.

\section{Material and Methods}

Patients who underwent appendectomy between January 2015 and January 2020 with a preliminary diagnosis of AA, at Erciyes University Faculty of Medicine General Surgery Clinic, were included in the study. The patient files and hospital information system records were examined and a database was created. Using this database, the cases were analysed retrospectively. We did not receive an ethics committee approval because the study is retrospective. Patients who underwent appendectomy with the diagnosis of AA and whose pathology reports were available were included in the study. Patients younger than 18 years of age, pregnant patients, patients with heart failure, peripheral vascular disease, haematological disease or liver disease, patients with anticoagulant and steroid use, patients with other acute or chronic infections, patients with a pathological result showing a tumour and patients whose records could not be accessed were excluded.

Patients were divided into two groups according to histopathological evaluation: group 1 (negative appendectomy) and group 2 (AA). In the groups, demographic data such as age, sex and preoperative laboratory findings (lymphocyte count $/ \mathrm{mm}^{3}$, platelet count/ $\mathrm{mm}^{3}$ ) and PLR at the time of admission were compared between groups 1 and 2. In addition, the groups were divided into subgroups based on age: 18-39 years, 40-59 years and 60 years and older. The same parameters were compared between the age groups.

The total blood count was measured by an automated haematology analyzer (Roche Hitachi Cobas ${ }^{\circledR} 8000$ Roche Diagnostics, Indianapolis, IN, USA). PLR was calculated for each subject by dividing the platelet count to the lymphocyte count.

\section{Statistical Analysis}

SPSS (Statistical Package for the Social Sciences) 23.0 package programme was used in the statistical analysis of the data. Categorical measurements were summarised as numbers and percentages and continuous measurements as mean and standard deviation (median and minimum-maximum where necessary). Pearson chi-square test statistics were used to compare categorical variables. Shapiro-Wilk test was used to determine whether the parameters in the study showed normal distribution. In comparing the continuous measurements between the groups, the distributions were 
checked and the independent student t-test was used for the parameters that showed normal distribution in the calculation of the binary variables and the Mann-Whitney $\mathrm{U}$ test was used for the parameters not showing normal distribution and the analysis of variance and Kruskal-Wallis tests were used when there were more than two variables. Logistic regression analysis was applied to determine the independent variables affecting the dependent variable. In order to generate a cut-off value for the PLR value, ROC analysis and ROC curve were created The patients were divided into two groups according to pathologic results and cut-off value was found by ROC analysis In the study, the cut-off value was determined by calculating the sensitivity and specificity values based on the PLR of the patients and examining the area under the ROC curve. Statistical significance level was taken as 0.05 in all tests.

\section{Results}

A total of 875 patients were included in the study. The patients were divided into two groups: group 1 consisted of patients with negative appendectomy and group 2 consisted of patients with AA. There were 152 patients in group 1 and 723 patients in group 2. Mean age was similar between the groups ( 33.43 vs $35.33 ; p=0.152$ ). Female sex was more dominant in group 1 ( $52 \%$ vs $43.1 \% ; \mathrm{p}=0.0285$ ). Lymphocyte count was lower in group 2 (1936 vs 1753; $\mathrm{p}=0.033)$, platelet count was higher in group $1(267,000$ vs 246,$000 ; p=0.002)$. PLR was similar between the groups (171 vs 184; $\mathrm{p}=0.382$ ). These parameters were independent variables in the diagnosis of AA in multivariate logistic regression analysis. The comparison between groups 1 and 2 is detailed in Table 1.

The ROC curve analyses of these independent variables are shown in Figure 1. The proposed cut-off values and performance characteristics for these variables are shown in Table 2.

When the patients were subdivided according to age, there were 588 patients aged 18-39 years, 195 patients aged 40-59 years and 68 patients aged 60 and older. Male sex was higher in all groups $(56.5 \%, 57.9 \%$ and $52.9 \%$, respectively). The lymphocyte count was the lowest in the 60 and older age group (1.86, 1.68, 1.36, respectively; $\mathrm{p}=0.000$ ). The platelet count was the highest in the 60 and older group $(169,207,218$, respectively; $\mathrm{p}=0.002)$. PLR was

Table 1. Comparison of the two groups

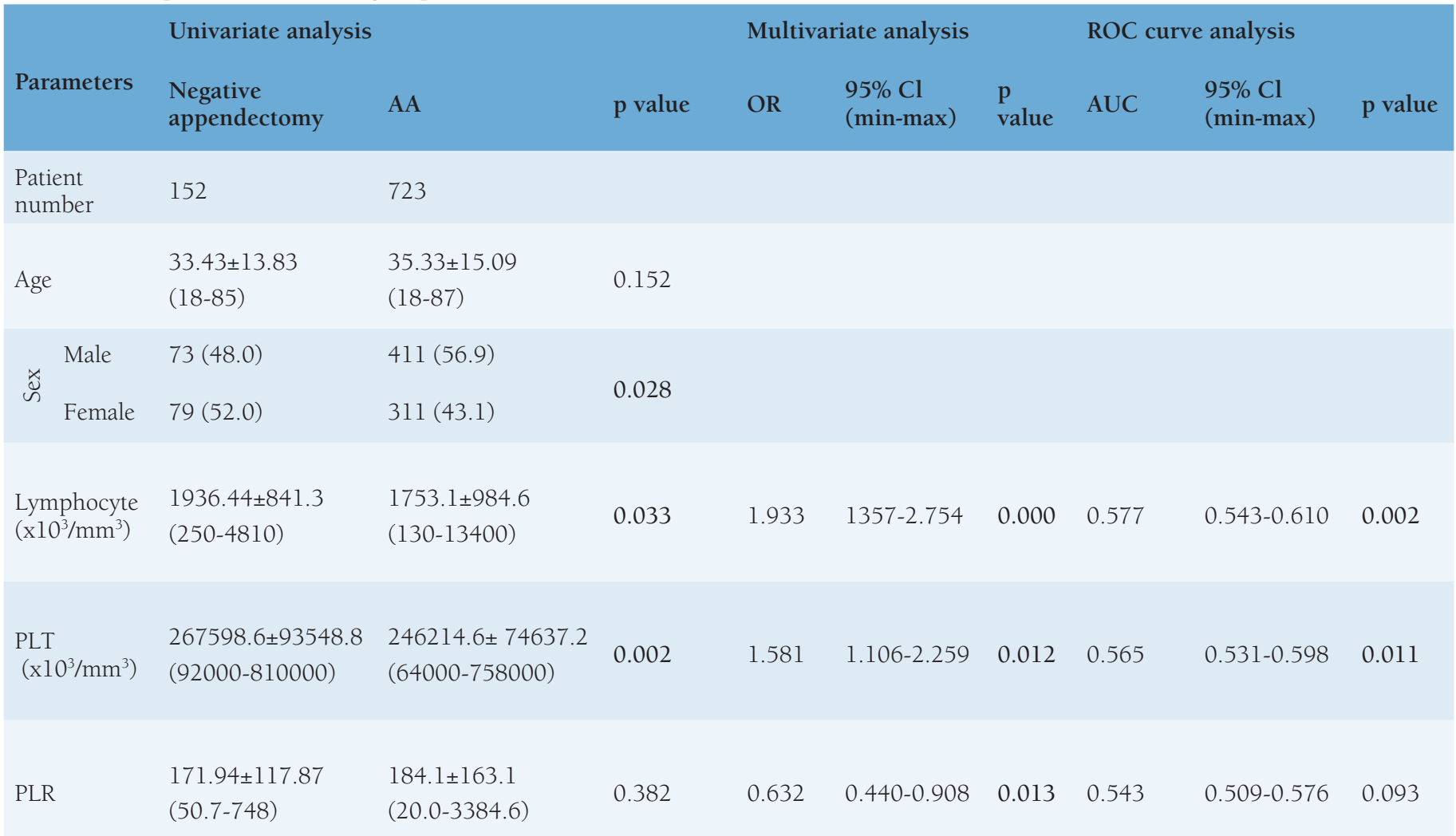


highest in the 40-59 age group (248, 255, 241, respectively; $\mathrm{p}=0.346$ ). Lymphocyte count, platelet count and PLR were independent variables in the diagnosis of AA in multivariate logistic regression analysis. Comparison between groups by age is given in detail in Table 3. In the ROC curve analyses of these independent variables in age groups, AUC was above 0.600 for the $18-39$ and $40-59$ age groups. ROC curve analyses for PLR are given in Figure 2.
The diagnostic value of PLR varied between age groups. The highest specificity was for the 40-59 years group (85.71\%), the highest sensitivity was in the 60 and older group (78.79\%) ( $\mathrm{p}=0.002)$. The proposed cut-off values and performance characteristics for the PLR by age group are shown in Table 4. (a) Lymphocyte count

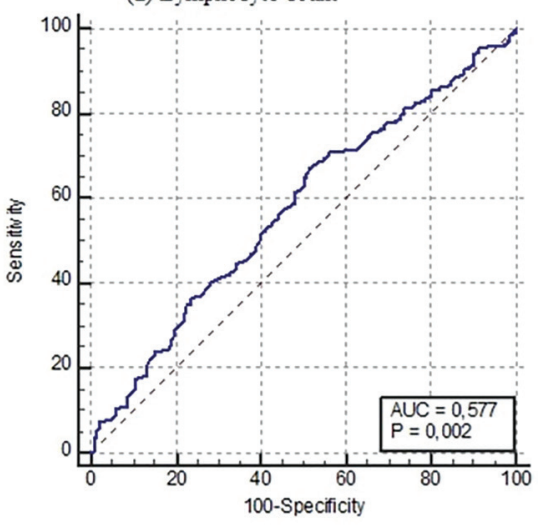

(b) Platelet count

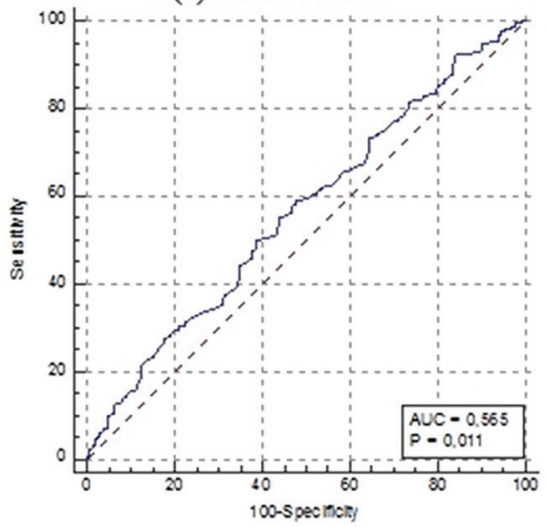

(c) Platelet-to-lymphocyte ratio (PLR)

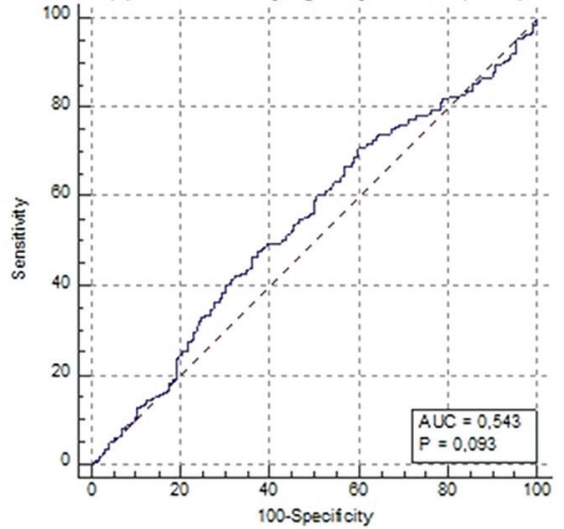

Figure 1. Receiver operating characteristic (ROC) curve analyses of significant parameters for the diagnosis of acute appendicitis: (a) Lymphocyte count, (b) Platelet count, (c) Platelet-to-lymphocyte ratio (PLR)

(a) Age 18-39

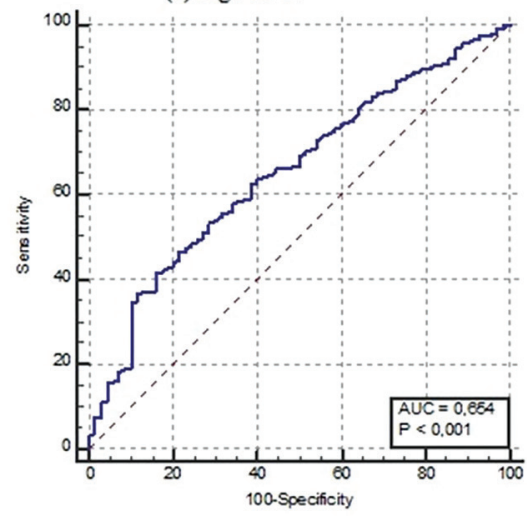

(b) Age 40-59

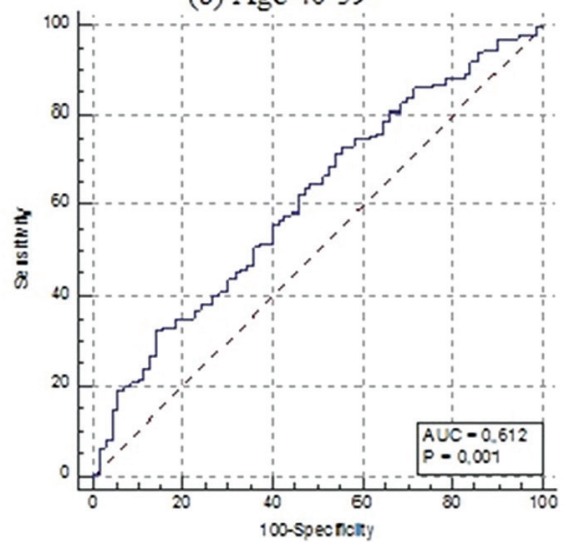

(c) 60 and older

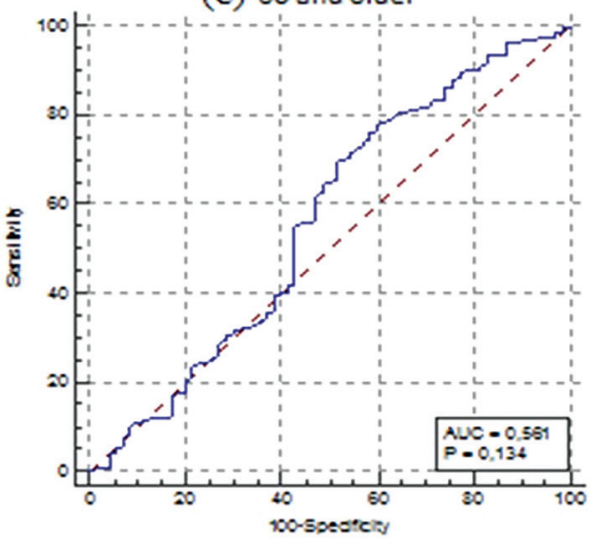

Figure 2. Receiver operating characteristic (ROC) curve analyses of PLR for the diagnosis of acute appendicitis in the age subgroups

Table 2. Proposed cut-off values for significant parameters in the diagnosis of AA

\begin{tabular}{llllllllll} 
& $\begin{array}{l}\text { Cut-off } \\
\text { value }\end{array}$ & $\begin{array}{l}\text { Sensitivity } \\
(\%)\end{array}$ & $\begin{array}{l}\text { Specificity } \\
(\%)\end{array}$ & PPV & NPV & OR & pLLR & nLRR & AUC \\
\hline Lymphocyte $\left(\mathrm{x} 10^{3} / \mathrm{mm}^{3}\right)$ & 1960 & 67.08 & 48.68 & 86.1 & 23.7 & 1.16 & 1.31 & 0.68 & 0.577 \\
PLT $\left(\mathrm{x} 10^{3} / \mathrm{mm}^{3}\right)$ & 235000 & 50.07 & 61.18 & 86.0 & 20.5 & 1.21 & 1.29 & 0.82 & 0.565 \\
PLR & 114.96 & 70.82 & 40.13 & 84.9 & 22.4 & 4.17 & 1.18 & 0.73 & 0.543
\end{tabular}

PLR: Platelet-to-lymphocyte ratio, NLR: Neutrophil-to-lymphocyte ratio, PLT: Platelet count, AUC: Area under the curve, PPV: Positive predictive value, NPV: Negative predictive value, OR: Odds ratio, pLLR: Positive likelihood ratio, nLLR: Negative likelihood ratio 


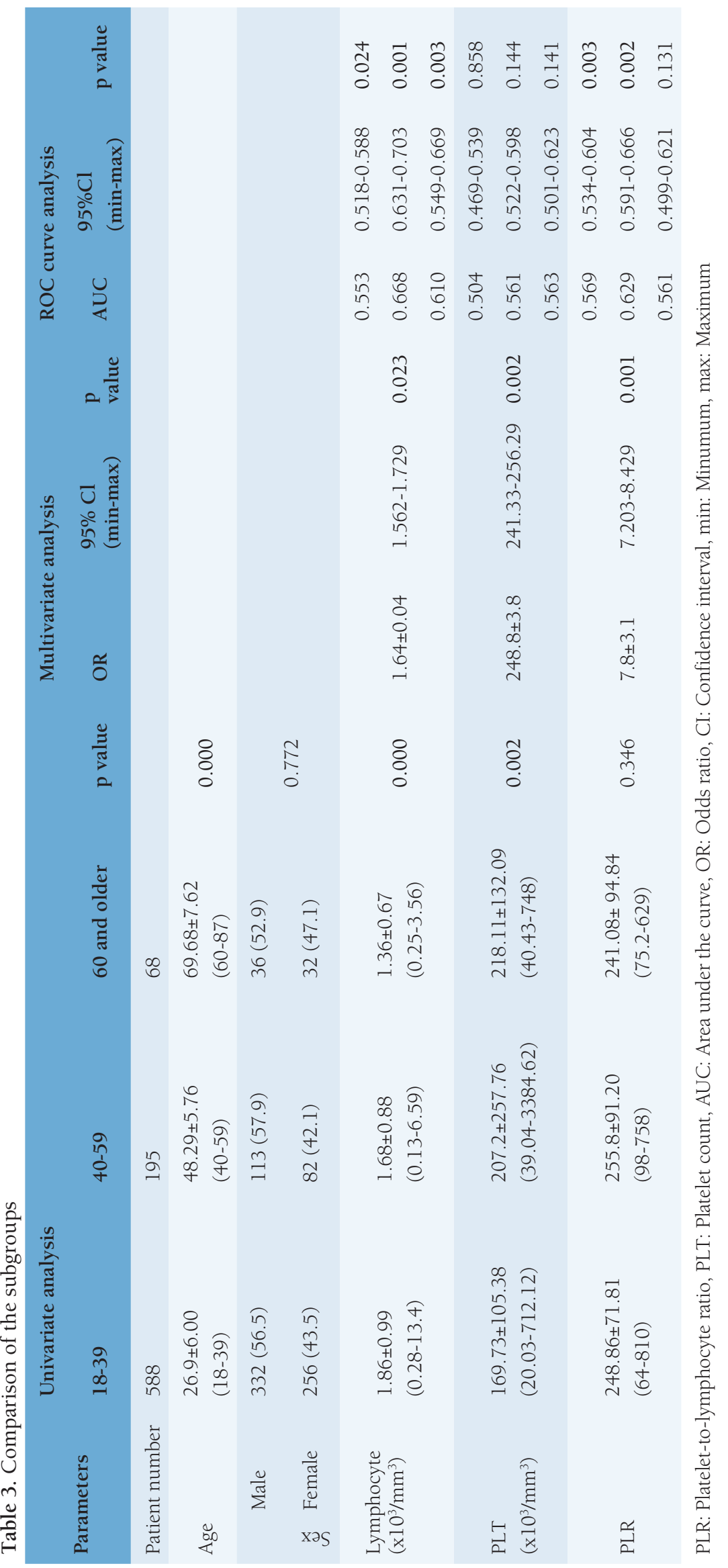

\section{Discussion}

The evaluation and treatment of pathologies that cause an acute abdomen presentation can vary depending on the age and sex of the patient. Although very detailed medical history taking and physical examination are performed, use of laboratory and radiological research is inevitable in cases requiring differential diagnosis.

In line with the studies in the literature, male sex was dominant in the AA group, while female sex was dominant in the negative appendectomy group., ${ }^{2,7}$ Our negative appendectomy rate was $17.3 \%$. We attributed our negative appendectomy rate, which was higher than in the literature, to the fact that we are a tertiary education hospital and that our patients had many additional diseases and a wide range of admission reasons.

Finding suitable, easily accessible and lowcost markers for early diagnosis of AA is often the focus of research. PLR is an inflammatory marker that can be identified in a simple haemogram examination. PLR is a tool to study important inflammatory cases. In many cancers and inflammatory processes, the release of proinflammatory cytokines promotes the proliferation of megakaryocytes and because platelets are cells that have a certain effect on infections, changes in PLR level can be used in the diagnosis and/or differential diagnosis of appendicitis. ${ }^{10,11}$

In AA, neutrophilia and a left shift on the haemogram are often associated with lymphopenia. ${ }^{12}$ Boshnak et al. ${ }^{13}$ found that low lymphocyte count is a risk factor in both univariate and multivariate analyses. When they took lymphocyte count [odds ratio (OR): 0.0125 ; 95\% confidence interval (CI), 0.0015-0.1031; $\mathrm{p}<0.001$ ] with a cut-off value of $2.3 \times 10^{9} / \mathrm{L}$, sensitivity was $82.76 \%$, specificity was $63.64 \%$, positive predictive value (PPV) was $85.7 \%$ and negative predictive value (NPV) was $58.3 \%$. In the same study, they found a mean platelet count $\left(x 10^{9} / \mathrm{L}\right)$ of $237.45 \pm 54.08$ in the AA group and $257.00 \pm 48.55(\mathrm{p}=0.02)$ in the negative appendectomy group. When the cut-off for the platelet value was taken as $188 \times 10^{9} / \mathrm{L}$, sensitivity was $31.03 \%$, specificity was $100 \%$, 
Table 4. Proposed cut-off values for PLR in diagnosis of AA to age groups

$\begin{array}{llllllllll}\text { Age groups } & \text { Cut-off value } & \text { Sensitivity (\%) } & \text { Specificity (\%) } & \text { p-value } & \text { PPV } & \text { NPV } & \text { pLLR } & \text { nLRR } & \text { AUC } \\ 18-39 & 125.80 & 43.07 & 70.71 & & 81.8 & 28.9 & 1.47 & 0.81 & 0.654 \\ 40-59 & 115 & 35.48 & 85.71 & 0.002 * & 95.6 & 13.3 & 2.48 & 0.75 & 0.612 \\ 60 \text { and older } & 233.64 & 78.79 & 34.29 & & 77.2 & 36.4 & 1.20 & 0.62 & 0.561\end{array}$

NLR: Neutrophil-to-lymphocyte ratio, AUC: Area under the curve, PPV: Positive predictive value, NPV: Negative predictive value, OR: Odds ratio, pLLR: Positive likelihood ratio, nLLR: Negative likelihood ratio

PPV was $100 \%$ and NPV was $35.5 \% .{ }^{13}$ In our series, similar to the literature, the lymphocyte count and platelet count were lower in the AA group.

In a study investigating the relationship between appendicitis and PLR in paediatric patients, the PLR level in the AA group was statistically significantly higher than the control group $(\mathrm{p}<0.001)$. In addition, when cut-off was taken as $>111.62$, the predictive power of PLR for patients with appendicitis [area under the curve (AUC): 0.706; 95\% CI, 0.658-0.751; $\mathrm{p}<0.001]$ had $65.7 \%$ sensitivity and $68.0 \%$ specificity. ${ }^{14}$

Kahramanca et al. ${ }^{15}$ found higher PLR values in the positive appendectomy group than in the negative appendectomy

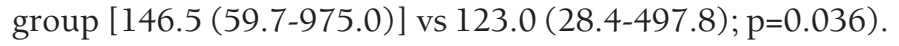
In their study, the cut-off value for PLR was 136.5; sensitivity, specificity, NPV and PPV were 56.3, 55.3\%, 19.6\% and $86.2 \%$, respectively.

In the study by Yildirım et al. ${ }^{9}$, PLR could also predict complicated cases regardless of age and sex $(p<0.001)$. While the cut-off value of the PLR was 169.7 , it had $74.4 \%$ sensitivity and $73.5 \%$ specificity in predicting complicated cases.

In our study, although the rate of PLR was high in patients with AA, there was no statistically significant difference (171 vs 184; $\mathrm{p}=0.382$ ). In multivariate analysis, PLR was a risk factor in the diagnosis of AA independent of age and sex (OR: 0.632; 95\% CI, (min-max) 0.440-0.908; p=0.013). When age-independent ROC curve was performed (AUC: 0.543; $\mathrm{p}=0.093$ ), its sensitivity was $70.82 \%$, specificity was $40.13 \%$ and its diagnostic value was limited. In our study, we evaluated the diagnostic value of PLR rate separately in the age groups, as compared to the studies in the literature and the diagnostic values for the age groups were significantly different. While it had the highest sensitivity in patients older than 60 years, its specificity was quite low. Between 40 and 59 years of age, its sensitivity was very low, but it showed the highest specificity.

\section{Study Limitations}

The most important limitation of our study was its retrospective nature. In addition, only patients undergoing appendectomy were included in the study, patients who had suspected AA but did not undergo surgery were not included.

\section{Conclusion}

Consequently, PLR value alone is not sufficient in diagnosis of AA and normal PLR values cannot exclude AA alone. The diagnostic value of PLR varies according to age groups. The surgeon's clinical evaluation should continue to be a priority in the diagnosis of AA. Prospective randomised studies are needed to determine the diagnostic accuracy of the PLR value.

\section{Ethics}

Ethics Committee Approval: We did not receive an ethics committee approval because the study is retrospective.

Informed Consent: Because the study was retrospective, we could not get informed consent.

Peer-review: Internally and externally peer reviewed.

\section{Authorship Contributions}

Surgical and Medical Practices: U.T., M.A., E.M.S., Ş.Y.İ., F.D., T.T., Concept: U.T., M.A., Design: U.T., M.A., Ş.Y.I, Data Collection or Processing: M.A., E.M.S., Analysis or Interpretation: U.T., S..Y.I., F.D., T.T., Literature Search: U.T., M.A., E.M.S., Ş.Y.İ., F.D., T.T., Writing: U.T., M.A.

Conflict of Interest: No conflict of interest was declared by the authors.

Financial Disclosure: The authors declared that this study received no financial support.

\section{References}

1. Pehlivanlı F, Aydin O. Role of platelet to lymphocyte ratio as a biomedical marker for the pre-operative diagnosis of acute appendicitis. Surg Infect (Larchmt) 2019;20:631-636.

2. Kahramanca S, Ozgehan G, Seker D, Gökce EI, Seker G, Tunç G, Küçükpınar T, Kargıcı H. Neutrophil-to-lymphocyte ratio as a predictor of acute appendicitis. Ulus Travma Acil Cerrahi Derg 2014;20:19-22.

3. Küçük E. The change of neutrophil lymphocyte ratio in acute appendicitis. Med-Science 2015;4:2379-2387.

4. Spangler R, Van Pham T, Khoujah D. Abdominal emergencies in the geriatric patient. Int J Emerg Med 2014;7:1-7. 
5. Güller U, Rosella L, McCall J, Brügger LE, Candinas D. Negative appendicectomy and perforation rates in patients undergoing laparoscopic surgery for suspected appendicitis. Br J Surg 2011;98:589-595.

6. Unnal Y. A new and early marker in the diagnosis of acute complicated appendicitis: immature granulocytes. Ulus Travma Acil Cerrahi Derg 2018;24:434-439

7. Sevinç MM, Kınacı E, Çakar E, Bayrak S, Özakay A, Aren A, Sarı S. Diagnostic value of basic laboratory parameters for simple and perforated acute appendicitis: an analysis of 3392 cases. Ulus Travma Acil Cerrahi Derg 2016;22:155-162.

8. McGoran DR, Sims HM, Zia K, Uheba M, Shaikh IA. The value of biochemical markers in predicting a perforation in acute appendicitis. ANZ J Surg 2013;83:79-83.

9. Yıldırım AC, Anuk T, Günal E, İrem B, Gülkan S. Clinical Value of the Platelet-to-Lymphocyte Ratio for Diagnosing Complicated Acute Appendicitis. Turk J Colorectal Dis 2017;27:1-5.

10. Yazar FM, Bakacak M, Emre A, Urfalıglu A, Serin S, Cengiz E, Bülbüloglu E. Predictive role of neutrophil-to-lymphocyte and platelet-to-lymphocyte ratios for diagnosis of acute appendicitis during pregnancy. Kaohsiung J Med Sci 2015;31:591-596.

11. Uncer AA, Cavus S, Balcioglu A, Silay S, Demiralp I, Calkan E, Altin MA, Eryilmaz E, Karaisaoglu AO, Bukulmez A, Dogan I, Embleton DB, Cetinkursun S. Can mean platelet volume, Neutrophil-to-Lymphocyte, Lymphocyte-to-Monocyte, Platelet-to-Lymphocyte ratios be favourable predictors for the differential diagnosis of appendicitis? J Park Med Assoc 2019;69:647-654.

12. Andersson RE. Meta-analysis of the clinical and laboratory diagnosis of appendicitis. Br J Surg 2004;91:28-37.

13. Boshnak N, Boshnaq M, Elgohary H. Evaluation of platelet indices and red cell distribution width as new biomarkers for the diagnosis of acute appendicitis. J Invest Surg 2018;31:121-129.

14. Duran İ, Avcı V, Nazik S, Altun E. Neutrophile Lymphocyte Ratio and Platelets Lymphocyte Ratio in the Diagnosis of Childhood Appendicitis. Turk J Biochem 2017;15:1-7.

15. Kahramanca Ş, Özgehan G, Kaya O, Küçükpınar TH, Kargıcı H, Avşar MF. Platelet to lymphocyte ratio and acute appendicitis. Kafkas J Med Sci 2017;7:153-157. 